\title{
Ginsenoside Rg3 suppresses the proliferation of prostate cancer cell line PC3 through ROS-induced cell cycle arrest
}

\author{
YANFEI PENG ${ }^{1}$, RAN ZHANG $^{2}$, XU YANG $^{2}$, ZHAIYI ZHANG $^{1}$, NING KANG ${ }^{1}$, \\ LIYING BAO ${ }^{1}$, YONGMEI SHEN ${ }^{2}$, HAO YAN $^{3}$ and FANG ZHENG ${ }^{1}$
}

\author{
${ }^{1}$ School of Integrative Medicine, Tianjin University of Traditional Chinese Medicine, Tianjin 301617; ${ }^{2}$ Bioactive Materials \\ Key Lab of Ministry of Education, Department of Biochemistry and Molecular Biology, College of Life Science, \\ Nankai University, Tianjin 300071; ${ }^{3}$ Department of Oncology, Institute of Integrative Oncology, \\ Tianjin Union Medicine Center, Tianjin 300000, P.R. China
}

Received March 3, 2018; Accepted October 12, 2018

DOI: $10.3892 / \mathrm{ol} .2018 .9691$

\begin{abstract}
To investigate the potential antitumor effects of ginsenoside $\operatorname{Rg} 3$ in prostate cancer cells, the androgen-insensitive prostate cancer cell line PC3 was cultured and incubated with ginsenoside $\operatorname{Rg} 3$ in vitro. Cell number counts, cell proliferation assays and senescence-associated $\beta$-galactosidase (SA- $\beta$-gal) staining were performed to evaluate cell proliferation. The results demonstrated that ginsenoside $\mathrm{Rg} 3$ led to cell proliferation arrest; ginsenoside $\operatorname{Rg} 3$ decreased the number of cells and increased the positive SA- $\beta$-gal staining rate in PC 3 cells. Cell cycle analysis by flow cytometry revealed that ginsenoside Rg3 interfered with the G1/S transition in PC3 cells. The mechanism involved in ginsenoside Rg3-induced cell proliferation arrest was then further investigated. This indicated that the level of reactive oxygen species (ROS) in PC3 cells was upregulated by ginsenoside Rg3 treatment. Furthermore, pretreatment with $\mathrm{N}$-acetyl-L-cysteine, a scavenger of ROS, was able to reverse the effects on cell number and cell cycle arrest induced by ginsenoside $\mathrm{Rg} 3$ in PC 3 cells. These results indicate that ginsenoside Rg3 exhibits anticancer effects on prostate cancer cells through ROS-mediated arrest of the cell cycle.
\end{abstract}

Correspondence to: Professor Fang Zheng, School of Integrative Medicine, Tianjin University of Traditional Chinese Medicine, 88 Yuquan Road, Tianjin 301617, P.R. China

E-mail: cfq_zf@tjutcm.edu.cn

Mrs. Hao Yan, Department of Oncology, Institute of Integrative Oncology, Tianjin Union Medicine Center, 190 Jieyuan Road, Tianjin 300000, P.R. China

E-mail: sarahhao99@sina.cn

Key words: cell cycle, cell proliferation arrest, ginsenoside $\operatorname{Rg} 3$, prostate cancer, reactive oxygen species

\section{Introduction}

Ginseng has been used as a traditional medical herb for thousands of years in Asian countries (1). Ginsenoside Rg3, one of the active ingredients extracted from ginseng, has demonstrated potential anticancer activity in multiple malignancy types (2). Previous research indicates that ginsenoside $\operatorname{Rg} 3$ is able to induce cell apoptosis $(3,4)$, attenuate cell migration and invasion (5-7), and enhance the sensitivity of cancer cells to chemotherapy $(8,9)$. Similar research has been performed in prostate cancer, a common malignancy in elderly males (10). In such studies, ginsenoside $\mathrm{Rg} 3$ was identified to attenuate cell migration by inhibiting the expression of aquaporin 1 (11) and to enhance the antitumor effects of docetaxel in prostate cancer cells (12). At a high dosage $(250 \mu \mathrm{M})$, ginsenoside $\operatorname{Rg} 3$ has also been revealed to induce cell apoptosis in the prostate cancer cell line LNCaP (13). However, to the best of our knowledge, the exact role of ginsenoside $\operatorname{Rg} 3$ and the molecular mechanism involved in its effects on prostate cancer cells remains to be fully understood.

Reactive oxygen species (ROS) consist of reactive oxygen ions and peroxides. ROS are produced in normal metabolic processes and at high concentrations they can cause detrimental effects on biomolecules, including nucleic acids, proteins and lipids (14). In several cancer cell lines, ginsenoside Rg3 exerts its anticancer activity by modulating the intracellular ROS level. However, the regulatory effects of ginsenoside $\operatorname{Rg} 3$ on ROS levels are not consistent among different cancer cell types. The accumulation of ROS induced by ginsenoside $\mathrm{Rg} 3$ has been observed in hepatoma, breast cancer, glioblastoma, leukemia and Jurkat cells, and has been identified to contribute to cancer cell apoptosis (15-18). However, one study has demonstrated that in Lewis lung carcinoma cells, ginsenoside $\mathrm{Rg} 3$ induces tumor cell apoptosis by reducing intracellular ROS (3). These previous studies indicate that ginsenoside Rg3 exhibits various effects on different types of cancer cells through the modulation of ROS. However, to the best of our knowledge, few studies have investigated the role of ginsenoside $\mathrm{Rg} 3$ in modulating the levels of ROS in prostate cancer cells.

The present study identified that ginsenoside $\mathrm{Rg} 3$ significantly increases the number of intracellular ROS in a 
dose-dependent manner and subsequently induces cell cycle arrest but not apoptosis in the prostate cancer cell line PC3.

\section{Materials and methods}

Cells and reagents. $\mathrm{PC} 3$, a prostate cancer cell line, was obtained from the German Cancer Research Center (Heidelberg, Germany) and cultured in RPMI-1640 medium (Sigma-Aldrich; Merck KGaA, Darmstadt, Germany) supplemented with $10 \%$ fetal bovine serum (Invitrogen; Thermo Fisher Scientific, Inc., Waltham, MA, USA), at $37^{\circ} \mathrm{C}$ and $5 \% \mathrm{CO}_{2}$.

Drugs. Ginsenoside Rg3 (Tianjin YiFang S\&T Co., Ltd., Tianjin, China) was dissolved in dimethylsulfoxide (DMSO) at $100 \mathrm{mM}$. N-acetyl-L-cysteine (NAC; Beyotime Institute of Biotechnology, Haimen, China) was dissolved at $1 \mathrm{M}$ in PBS.

Senescence-associated $\beta$-galactosidase (SA- $\beta$-gal) staining. PC3 cells were cultured in six-well plates at a density of $5 \times 10^{5}$ cells/well and treated with DMSO or $50 \mu \mathrm{M}$ ginsenoside $\mathrm{Rg} 3$ for $48 \mathrm{~h}$ at $37^{\circ} \mathrm{C}$ in an atmosphere of $5 \% \mathrm{CO}_{2}$, followed by SA- $\beta$-gal staining using Senescence $\beta$-Galactosidase Staining kit (Beyotime Institute of Biotechnology). Images were captured using a phase-contrast microscope (magnification, x200). In total, six fields of view were randomly selected in each well and the percentage of cells stained positive was calculated. The data are expressed as the mean \pm standard deviation (SD).

Cell count. PC 3 cells were digested with $0.5 \%$ trypsin (Yuanye S\&T, Shanghai, China) and suspended in RPMI-1640 medium. Cell counts were performed using a hemocytometer and a light microscope (magnification, x100). All data are expressed as the mean of triplicates \pm SD.

Cell proliferation assays. PC3 cells were seeded in 24-well plates at a density of $5 \times 10^{4}$ cells/well and on the following day they were treated with DMSO or ginsenoside Rg3 (25, 50 or $100 \mu \mathrm{M}$ ) for $72 \mathrm{~h}$ at $37^{\circ} \mathrm{C}$ in an atmosphere of $5 \%$ $\mathrm{CO}_{2}$. Cell Counting Kit-8 (CCK8) solution (US Everbright, Inc., San Ramon, CA, USA) was added to each well, followed by incubation at $37^{\circ} \mathrm{C}$ for $2 \mathrm{~h}$, according to the manufacturer's protocol. The absorbance of each well was measured at $450 \mathrm{~nm}$. All results are expressed as the mean of triplicates $\pm \mathrm{SD}$.

Cell cycle analysis. PC3 cells were treated with DMSO or $50 \mu \mathrm{M}$ ginsenoside $\mathrm{Rg} 3$ for $48 \mathrm{~h}$ at $37^{\circ} \mathrm{C}$ in an atmosphere of $5 \% \mathrm{CO}_{2}$. A cell cycle and apoptosis analysis kit (Beyotime Institute of Biotechnology) was used and flow cytometry assays were performed as described previously (19).

ROS assays. PC3 cells were plated in 24-well plates at a density of $5 \times 10^{4}$ cells/well and treated with DMSO or ginsenoside $\operatorname{Rg} 3(25,50$ or $100 \mu \mathrm{M})$ at $37^{\circ} \mathrm{C}$ for $72 \mathrm{~h}$ in an atmosphere of $5 \% \mathrm{CO}_{2}$. 2,7-Dichlorodihydrofluorescein diacetate stain (DCFH-DA) was diluted to $10 \mu \mathrm{M}$ in serum-free RPMI-1640 medium and was used to treat PC3 cells for 20 min at $37^{\circ} \mathrm{C}$. Subsequently, cells were washed with serum-free RPMI-1640 medium three times. An ROS assay kit (Beyotime Institute of Biotechnology) was used to evaluate ROS levels according to the manufacturer's protocol. Images were captured using a fluorescence microscope (magnification, x100).

NAC treatment. PC3 cells were cultured in 24-well plates at a density of $5 \times 10^{4}$ cells/well. The following day, the cells were precultured with $10 \mathrm{mM}$ NAC for $2 \mathrm{~h}$, followed by treatment with DMSO or $50 \mu \mathrm{M}$ ginsenoside $\operatorname{Rg} 3$ for a further $0,24,48$ and $96 \mathrm{~h}$ at $37^{\circ} \mathrm{C}$ in an atmosphere of $5 \% \mathrm{CO}_{2}$. Cell counts were performed with a hemocytometer and a light microscope (magnification, x100). All data are expressed as the mean of triplicates \pm SD.

Statistical analysis. All statistical analysis was performed using SPSS software (version 23.0; IBM Corp., Armonk, NY, USA). Data are presented as the mean $\pm \mathrm{SD}$. Analysis of variance (ANOVA) was performed to analyze the data. One-way ANOVA was used for complete random designed data and repeated measures ANOVA was used for repeated measured designed data. A Fisher's least significant difference test was used to perform multiple comparisons. $\mathrm{P}<0.05$ was considered to indicate a statistically significant difference.

\section{Results}

Ginsenoside Rg3 inhibits PC3 cell proliferation in vitro. PC3 prostate cancer cells were seeded in six-well plates and treated with DMSO or $50 \mu \mathrm{M}$ ginsenoside $\mathrm{Rg} 3$ for $48 \mathrm{~h}$. SA- $\beta$-gal staining revealed that ginsenoside $\mathrm{Rg} 3$ significantly increased the percentage of positively stained cells (Fig. 1A). The cells were then cultured in 24 -well plates at $5 \times 10^{4}$ cells/well, followed by treatment with DMSO or $50 \mu \mathrm{M}$ ginsenoside $\mathrm{Rg} 3$ for $72 \mathrm{~h}$. The number of cells in each well was counted and cell proliferation was evaluated using a CCK8 assay. The results demonstrated that ginsenoside $\operatorname{Rg} 3$ exhibited significant inhibitory effects on cell proliferation in vitro compared with DMSO (Fig. 1B and C).

Ginsenoside Rg3 inhibits the G1/S transition in the PC3 cell cycle. To further study the molecular mechanism involved in the inhibition of cell proliferation by ginsenoside $\operatorname{Rg} 3$, flow cytometry analysis was performed to examine the cell cycle of PC 3 cells treated with DMSO or $50 \mu \mathrm{M}$ ginsenoside $\mathrm{Rg} 3$ for $48 \mathrm{~h}$. Ginsenoside Rg3 significantly induced cell cycle arrest in the $\mathrm{G}_{0} / \mathrm{G}_{1}$ phase and significantly decreased the percentage of cells in the $\mathrm{S}$ phase (Fig. 2). These results indicate that treatment with ginsenoside $\mathrm{Rg} 3$ inhibits cell cycle transition from the $\mathrm{G}_{1}$ phase to the $\mathrm{S}$ phase in $\mathrm{PC} 3$ cells. However, apoptosis of PC 3 cells induced by ginsenoside Rg3 was not observed in the current study according to the results of flow cytometry assays (data not shown).

Ginsenoside Rg3 increases ROS levels in PC3 cells in a dose-dependent manner. Oxidative stress acts as a pivotal modulator in the proliferation and apoptosis of cancer cells, and an imbalance in the production and scavenging of ROS triggers the progression of cancer (20). In the current study, different doses of ginsenoside $\operatorname{Rg} 3(0,25,50$ and $100 \mu \mathrm{M})$ were used to treat $\mathrm{PC} 3$ cells cultured in 24 -well plates at $5 \times 10^{4}$ cells/well for $72 \mathrm{~h}$. Compared with the control group, cell counting and CCK8 
A
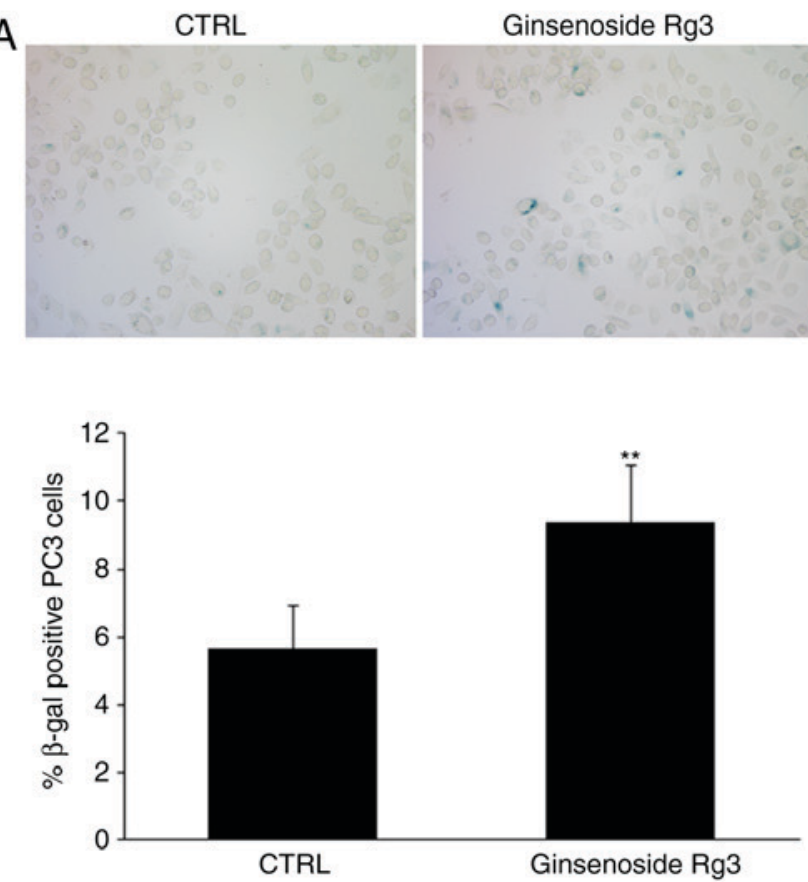

B

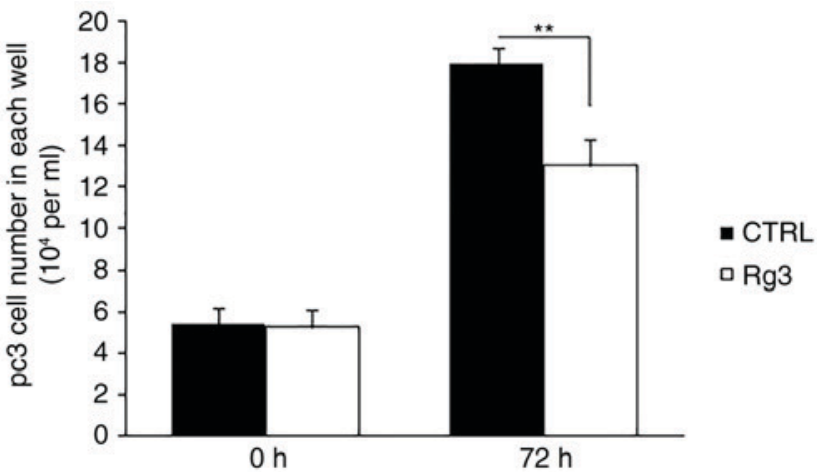

C

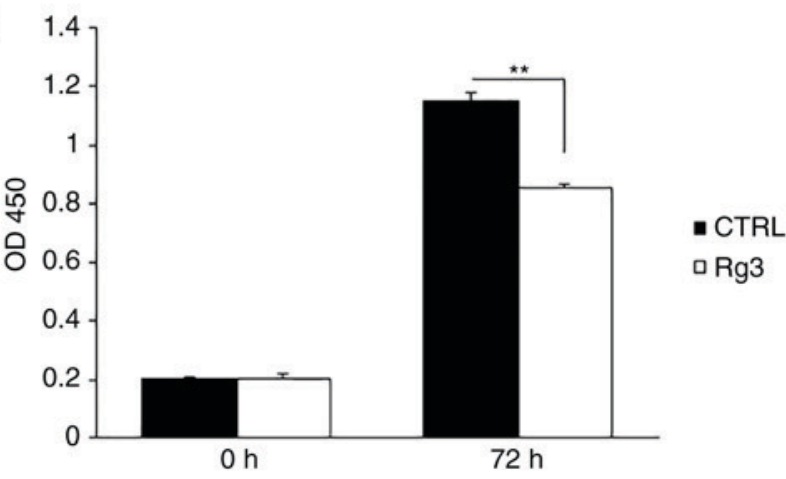

Figure 1. Ginsenoside Rg3 inhibits the proliferation of PC3 cells. (A) PC3 cells were treated with DMSO or $50 \mu \mathrm{M}$ ginsenoside Rg3 for $48 \mathrm{~h}$. SA- $\beta$-gal staining was performed and the percentage of positively stained cells was calculated. Magnification, $\mathrm{x} 200 .{ }^{* *} \mathrm{P}<0.01$ vs. CTRL. (B) PC 3 cells were treated with DMSO or $50 \mu \mathrm{M}$ ginsenoside Rg3 for $72 \mathrm{~h}$, followed by cell number counting. (C) PC 3 cells were treated with DMSO or $50 \mu \mathrm{M}$ ginsenoside Rg3 for $72 \mathrm{~h}$, followed by Cell Counting Kit- 8 assays. ${ }^{* *} \mathrm{P}<0.01$. All data were obtained from three independent experiments and are presented as the mean \pm standard deviation. DMSO, dimethylsulfoxide; CTRL, control; $\beta$-gal, $\beta$-galactosidase; Rg3, ginsenoside Rg3; OD, optical density.

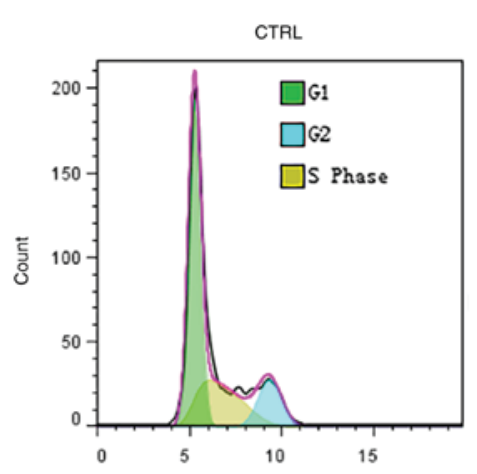

RED-B-HLin:: Red-B fluorescence (RED-B-HLin)

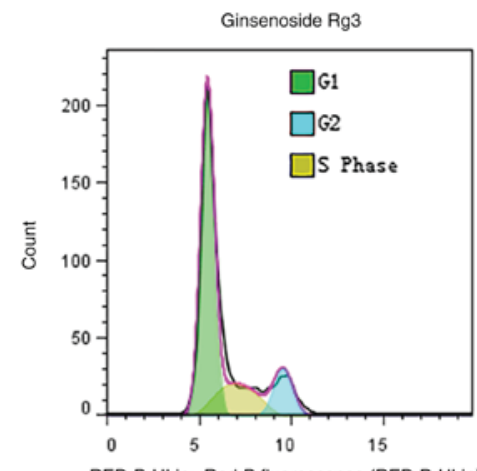

RED-B-HLin:: Red-B fluorescence (RED-B-HLin)

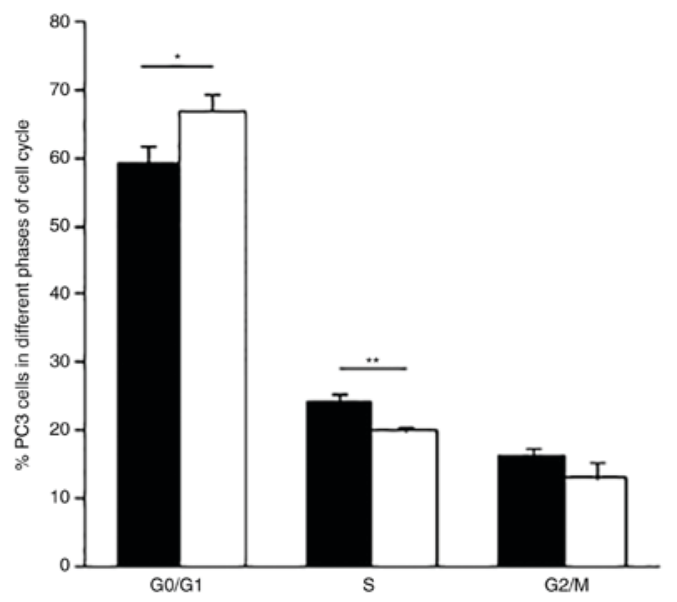

Figure 2. Ginsenoside Rg3 induces cell cycle arrest in PC3 cells. PC 3 cells were treated with dimethylsulfoxide or $50 \mu \mathrm{M}$ ginsenoside Rg3 for $48 \mathrm{~h}$, followed by flow cytometry analysis. All data were obtained from three independent experiments and are presented as the mean \pm standard deviation. ${ }^{*} \mathrm{P}<0.05,{ }^{* *} \mathrm{P}<0.01$. CTRL, control. 

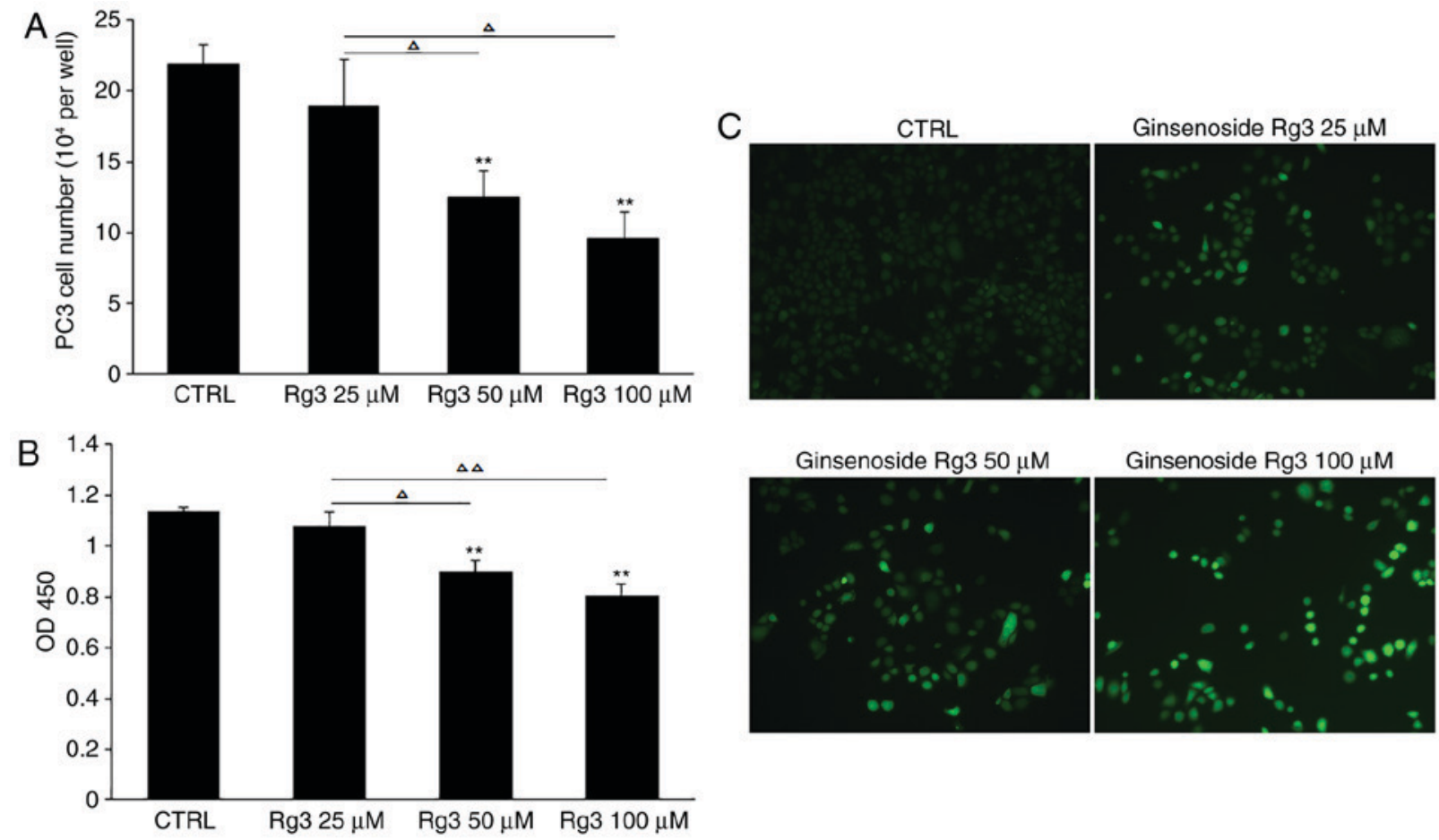

Figure 3. Ginsenoside Rg3 inhibits cell proliferation and induces the accumulation of ROS in PC3 cells in a dose-dependent manner. (A) PC3 cells were treated with various doses of ginsenoside $\operatorname{Rg} 3(0,25,50$ and $100 \mu \mathrm{M})$ for $72 \mathrm{~h}$, followed by cell counting. (B) Cell proliferation was measured by Cell Counting Kit-8 assay. (C) 2,7-Dichlorodihydrofluorescein diacetate staining was performed to evaluate the level of ROS. Images were captured using a fluorescence microscope. Magnification, $\mathrm{x} 100$. All data were obtained from three independent experiments and are presented as the mean \pm standard deviation. ${ }^{* *} \mathrm{P}<0.01 \mathrm{vs}$. CTRL, ${ }^{\Delta} \mathrm{P}<0.05,{ }^{\Delta \triangle} \mathrm{P}<0.01$. ROS, reactive oxygen species; Rg3, ginsenoside Rg3; CTRL, control; OD, optical density; CTRL, control.

analysis demonstrated that 50 and $100 \mu \mathrm{M}$ ginsenoside $\operatorname{Rg} 3$ significantly inhibited cell proliferation. In addition, compared with $25 \mu \mathrm{M}$ ginsenoside Rg3 treatment, 50 and $100 \mu \mathrm{M}$ ginsenoside Rg3 exhibited significant inhibitory effects on PC3 cell proliferation (Fig. 3A and B). In addition, DCFH-DA staining was performed to evaluate ROS levels and an accumulation of intracellular ROS was observed in PC3 cells, suggesting a potential association between ginsenoside Rg3-induced cell cycle arrest and increased levels of ROS (Fig. 3C).

Elimination of intracellular ROS with NAC can block ginsenoside Rg3-induced cell cycle arrest in PC 3 cells. To investigate the effect of intracellular ROS accumulation on the arrest of cell proliferation induced by ginsenoside Rg3, PC3 cells were precultured with $10 \mathrm{mM} \mathrm{NAC}$ for $2 \mathrm{~h}$, followed by treatment with DMSO or $50 \mu \mathrm{M}$ ginsenoside $\mathrm{Rg} 3$ for a further $0,24,48$ and $96 \mathrm{~h}$. Cell counting revealed that the elimination of intracellular ROS by NAC significantly blocked the ginsenoside Rg3-induced proliferation inhibition in PC3 cells (Fig. 4A). Flow cytometry analysis was also performed $48 \mathrm{~h}$ following treatment with DMSO or ginsenoside $\mathrm{Rg} 3$ in PC3 cells. Pretreatment with NAC decreased the cell cycle arrest caused by ginsenoside $\operatorname{Rg} 3$ and reestablished the transition of PC3 cells from the $G_{1}$ phase to the $S$ phase. The results indicated that compared with the control group, ginsenoside $\mathrm{Rg} 3$ significantly increased the proportion of cells in the in $G_{0} / G_{1}$ phase and decreased the proportion of cells in the $\mathrm{S}$ phase. However, no significant differences were identified in the proportion of cells in the $\mathrm{G}_{0} / \mathrm{G}_{1}$ phase or the $\mathrm{S}$ phase when treated with NAC or NAC+Rg3 compared with the control (Fig. 4B).

\section{Discussion}

Oxidative stress is a pivotal factor associated with the pathology of prostate cancer (20). A previous study has identified that the accumulation of ROS induced by a redox disorder can contribute to carcinogenesis resulting from epigenetic regulation and macromolecular damage, including DNA instability (21). Therefore, certain antioxidants are assumed to have therapeutic value in the treatment of prostate cancer (22). The Selenium and Vitamin E Cancer Prevention Trial study was performed with a large sample size and long duration to evaluate the benefits of selenium and vitamin E supplementation in the treatment of prostate cancer, however, the study failed to identify any benefits (23). Therefore, previous studies suggest that antioxidant therapy in cancer treatment requires further assessment.

Antioxidants may provide a feasible strategy for cancer treatment in the early stage of disease, however, they may not provide a feasible strategy in the later stages, particularly in cases involving high levels of ROS that are below the toxic threshold. At the later stages of disease, decreased levels of ROS may have no effects on the progression of cancer or may even exhibit procarcinogenic effects (24).

The current study identified that increased levels of ROS inhibited the proliferation of PC3 cells. However, using a different prostate cancer cell line, DU145, it was revealed that ginsenoside Rg3 increased the intracellular level of ROS but enhanced cell viability, instead of inducing cell proliferation arrest or cell death (data not shown). This result may partially be due to a distinct tolerance of ROS in the two cell lines. 


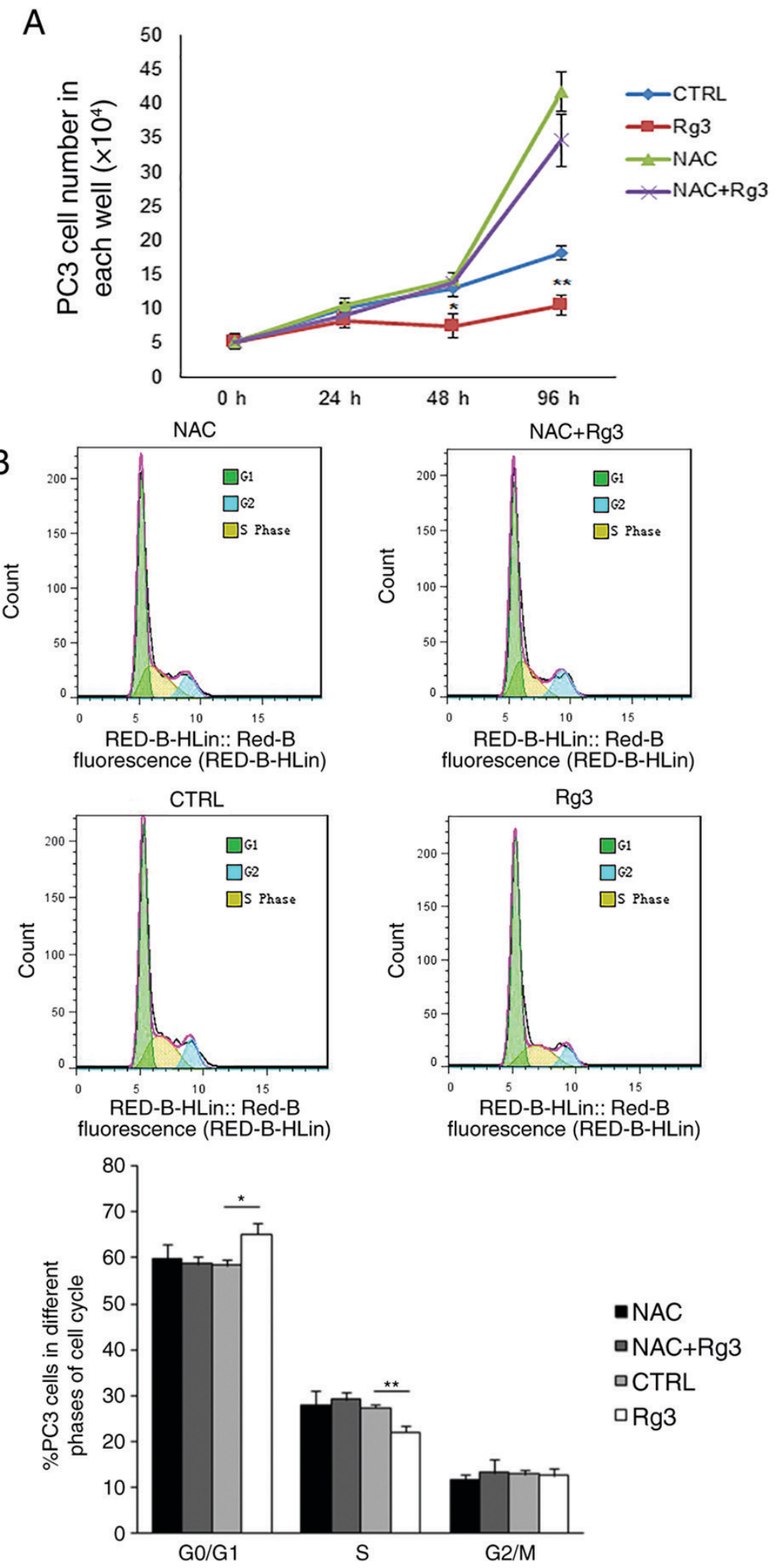

Figure 4. NAC reverses ginsenoside Rg3-inhibited PC3 cell proliferation. (A) PC3 cells were precultured with $10 \mathrm{mM}$ NAC for $2 \mathrm{~h}$ and then treated with $50 \mu \mathrm{M}$ ginsenoside $\mathrm{Rg} 3$ for $0,24,48$ and $96 \mathrm{~h}$, followed by cell counting. Cell number was significantly decreased with ginsenoside $\mathrm{Rg} 3$ treatment at 48 and $96 \mathrm{~h}$ compared with the control. However, no significant differences of cell number were observed between the NAC and NAC+Rg3 groups at each time point. ${ }^{*} \mathrm{P}<0.05,{ }^{* *} \mathrm{P}<0.01$ vs. CTRL. (B) PC3 cells were precultured with $10 \mathrm{mM} \mathrm{NAC}$ for $2 \mathrm{~h}$ and then treated with $50 \mu \mathrm{M}$ ginsenoside Rg3 for $48 \mathrm{~h}$. Flow cytometry analysis was performed to investigate the cell cycle. ${ }^{*} \mathrm{P}<0.05$; ${ }^{* *} \mathrm{P}<0.01$. All data were obtained from three independent experiments and are presented as the mean \pm standard deviation. NAC, N-acetyl-L-cysteine; CTRL, control; Rg3, ginsenoside Rg3.

A previous study compared the responses of PC3 cells and DU145 cells to ionizing radiation; this revealed that DU145 cells exhibit a higher resistance to radiation due to lower basal levels of ROS, a higher glutathione (GSH) content and 
a higher GSH/glutathione disulfide ratio, suggesting DU145 cells possess a greater tolerance to radiation-induced ROS compared with PC3 cells (25). A recent study also identified that phosphatase and tensin homolog (PTEN)-deficient cancer cells with upregulated Akt exhibit high intracellular ROS levels and are more sensitive to ROS-induced cell death compared with PTEN wild-type cell lines (26). This may partially explain the different responses of the PTEN wild-type cell line DU145 and the PTEN-deficient cell line PC3 to ginsenoside Rg3-induced ROS accumulation (27). Therefore, ginsenoside $\mathrm{Rg} 3$ should be used with caution in the treatment of prostate cancer as the drug may serve either a pro-cancer or anticancer role depending on the subtype of the disease.

In the current study, ginsenoside $\mathrm{Rg} 3$ increased the levels of ROS in prostate cancer cells in a dose-dependent manner. A previous study has demonstrated that ginsenoside Rg3 downregulates ROS levels and inhibits cellular senescence in prostatic stromal cells (28). This suggests that ginsenoside Rg3 may conversely regulate ROS levels in prostate cancer cells and stromal cells. The molecular mechanism involved requires further investigation and the complex effects of ginsenoside $\mathrm{Rg} 3$ on both cancer cell types and the tumor microenvironment should be carefully considered before this agent is utilized in cancer treatment.

In summary, the current study revealed that ginsenoside $\mathrm{Rg} 3$ induces intracellular ROS accumulation in the prostate cancer cell line PC3 and subsequently inhibits cell proliferation via ROS-induced cell cycle arrest.

\section{Acknowledgements}

Not applicable.

\section{Funding}

The present study was supported by the Foundation of Tianjin Municipal Committee for Health and Family Planning (grant no. 2017111), the Natural Science Foundation in Tianjin (grant no. 16JCQNJC10700) and the National Natural Science Foundation of China (grant no. 81703828).

\section{Availability of data and materials}

All data generated or analyzed during the present study are included in this published article.

\section{Authors' contributions}

FZ and YP conceived and designed the experiments. YP, RZ, XY and NK performed the experiments. HY, LB, YS and $\mathrm{ZZ}$ analyzed the data. HY and $\mathrm{ZZ}$ wrote the manuscript. All authors have read and approved the final manuscript.

\section{Ethics approval and consent to participate}

Not applicable.

\section{Patient consent for publication}

Not applicable.

\section{Competing interests}

The authors declare that they have no competing interests.

\section{References}

1. Vayghan HJ, Ghadimi SS and Nourazarian AR: Preventive and therapeutic roles of ginseng-focus on colon cancer. Asian Pac J Cancer Prev 15: 585-588, 2014.

2. Sun M, Ye Y, Xiao L, Duan X, Zhang Y and Zhang H: Anticancer effects of ginsenoside Rg3 (Review). Int J Mol Med 39: 507-518, 2017.

3. Sun HY, Lee JH, Han YS, Yoon YM, Yun CW, Kim JH, Song YS and Lee SH: Pivotal roles of ginsenoside rg3 in tumor apoptosis through regulation of reactive oxygen species. Anticancer Res 36: 4647-4654, 2016.

4. Zhang F, Li M, Wu X, Hu Y, Cao Y, Wang X, Xiang S, Li H, Jiang L, Tan Z, et al: 20(S)-ginsenoside Rg3 promotes senescence and apoptosis in gallbladder cancer cells via the p53 pathway. Drug Des Devel Ther 9: 3969-3987, 2015.

5. Zheng X, Chen W, Hou H, Li J, Li H, Sun X, Zhao L and Li X: Ginsenoside 20(S)-Rg3 induced autophagy to inhibit migration and invasion of ovarian cancer. Biomed Pharmacother 85: 620-626, 2017.

6. Junmin S, Hongxiang L, Zhen L, Chao Y and Chaojie W: Ginsenoside Rg3 inhibits colon cancer cell migration by suppressing nuclear factor kappa B activity. J Tradit Chin Med 35: 440-444, 2015.

7. Tian L, Shen D, Li X, Shan X, Wang X, Yan Q and Liu J: Ginsenoside $\operatorname{Rg} 3$ inhibits epithelial-mesenchymal transition (EMT) and invasion of lung cancer by down-regulating FUT4. Oncotarget 7: 1619-1632, 2016.

8. Wang J, Tian L, Khan MN, Zhang L, Chen Q, Zhao Y, Yan Q, Fu L and Liu J: Ginsenoside Rg3 sensitizes hypoxic lung cancer cells to cisplatin via blocking of NF- $\kappa \mathrm{B}$ mediated epithelial-mesenchymal transition and stemness. Cancer Lett 415: 73-85, 2018.

9. Jiang J, Yuan Z, Sun Y, Bu Y, Li W and Fei Z: Ginsenoside Rg3 enhances the anti-proliferative activity of erlotinib in pancreatic cancer cell lines by downregulation of EGFR/PI3K/Akt signaling pathway. Biomed Pharmacother 96: 619-625, 2017.

10. Barnett CM, Nielson CM, Shannon J, Chan JM, Shikany JM, Bauer DC, Hoffman AR, Barrett-Connor E, Orwoll E and Beer TM: Serum 25-OH vitamin D levels and risk of developing prostate cancer in older men. Cancer Causes Control 21: 1297-1303, 2010.

11. Pan XY, Guo H, Han J, Hao F, An Y, Xu Y, Xiaokaiti Y, Pan Y and $\mathrm{Li}$ XJ: Ginsenoside $\mathrm{Rg} 3$ attenuates cell migration via inhibition of aquaporin 1 expression in PC-3M prostate cancer cells. Eur J Pharmacol 683: 27-34, 2012.

12. Kim SM, Lee SY, Cho JS, Son SM, Choi SS, Yun YP, Yoo HS, Yoon DY, Oh KW, Han SB and Hong JT: Combination of ginsenoside $\mathrm{Rg} 3$ with docetaxel enhances the susceptibility of prostate cancer cells via inhibition of NF-kappaB. Eur J Pharmacol 631: 1-9, 2010.

13. Liu WK, Xu SX and Che CT: Anti-proliferative effect of ginseng saponins on human prostate cancer cell line. Life Sci 67: 1297-1306, 2000.

14. Sanz A: Mitochondrial reactive oxygen species: Do they extend or shorten animal lifespan? Biochim Biophys Acta 1857: 1116-1126, 2016.

15. Park HM, Kim SJ, Kim JS and Kang HS: Reactive oxygen species mediated ginsenoside Rg3- and Rh2-induced apoptosis in hepatoma cells through mitochondrial signaling pathways. Food Chem Toxicol 50: 2736-2741, 2012.

16. Kim BM, Kim DH, Park JH, Na HK and Surh YJ: Ginsenoside Rg3 induces apoptosis of human breast cancer (MDA-MB-231) cells. J Cancer Prev 18: 177-185, 2013.

17. Choi YJ, Lee HJ, Kang DW, Han IH, Choi BK and Cho WH: Ginsenoside Rg3 induces apoptosis in the U87MG human glioblastoma cell line through the MEK signaling pathway and reactive oxygen species. Oncol Rep 30: 1362-1370, 2013.

18. Xia T, Wang YN, Zhou CX, Wu LM, Liu Y, Zeng QH, Zhang XL, Yao JH, Wang M and Fang JP: Ginsenoside Rh2 and Rg3 inhibit cell proliferation and induce apoptosis by increasing mitochondrial reactive oxygen species in human leukemia jurkat cells. Mol Med Rep 15: 3591-3598, 2017.

19. Wang C, Du X, Yang R, Liu J, Xu D, Shi J, Chen L, Shao R, Fan G, Gao X, et al: The prevention and treatment effects of tanshinone IIA on oestrogen/androgen-induced benign prostatic hyperplasia in rats. J Steroid Biochem Mol Biol 145: 28-37, 2015. 
20. Udensi UK and Tchounwou PB: Oxidative stress in prostate hyperplasia and carcinogenesis. J Exp Clin Cancer Res 35: 139, 2016.

21. Paschos A, Pandya R, Duivenvoorden WC and Pinthus JH: Oxidative stress in prostate cancer: Changing research concepts towards a novel paradigm for prevention and therapeutics Prostate Cancer Prostatic Dis 16: 217-225, 2013.

22. Mohsenzadegan M, Seif F, Farajollahi MM and Khoshmirsafa M: Anti-oxidants as chemopreventive agents in prostate cancer: A gap between preclinical and clinical studies. Recent Pat Anticancer Drug Discov 13: 224-239, 2018.

23. Ramamoorthy V, Rubens M, Saxena A and Shehadeh N: Selenium and vitamin E for prostate cancer-justifications for the SELECT study. Asian Pac J Cancer Prev 16: 2619-2627, 2015.

24. Assi M: The differential role of reactive oxygen species in early and late stages of cancer. Am J Physiol Regul Integr Comp Physiol 313: R646-R653, 2017.

25. Jayakumar S, Kunwar A, Sandur SK, Pandey BN and Chaubey RC: Differential response of DU145 and PC3 prostate cancer cells to ionizing radiation: Role of reactive oxygen species, GSH and Nrf2 in radiosensitivity. Biochim Biophys Acta 1840: 485-494, 2014.
26. Nogueira V, Patra KC and Hay N: Selective eradication of cancer displaying hyperactive Akt by exploiting the metabolic consequences of Akt activation. Elife 7: e32213, 2018

27. Isebaert SF, Swinnen JV, McBride WH and Haustermans KM: Insulin-like growth factor-type 1 receptor inhibitor NVP-AEW541 enhances radiosensitivity of PTEN wild-type but not PTEN-deficient human prostate cancer cells. Int J Radiat Oncol Biol Phys 81: 239-247, 2011

28. Peng Y, Zhang R, Kong L, Shen Y, Xu D, Zheng F, Liu J, Wu Q, Jia B and Zhang J: Ginsenoside Rg3 inhibits the senescence of prostate stromal cells through down-regulation of interleukin 8 expression. Oncotarget 8: 64779-64792, 2017.

This work is licensed under a Creative Commons Attribution-NonCommercial-NoDerivatives 4.0 International (CC BY-NC-ND 4.0) License. 